\title{
Quality Assessment and Shelf Life Modeling of Pulsed Electric Field Pretreated Osmodehydrofrozen Kiwifruit Slices
}

\author{
Efimia Dermesonlouoglou ${ }^{\mathrm{a}}$, Ismini Zachariou ${ }^{\mathrm{a}}$, Varvara Andreou ${ }^{\mathrm{a}}$, And Petros \\ S. TAOUKIS ${ }^{\mathrm{a}}$ \\ ${ }^{\text {a }}$ Laboratory of Food Chemistry \& Technology, School of Chemical Engineering, National Technical University \\ of Athens, Iroon Polytechniou 9, Zografou Campus, 15780 Athens, Greece \\ ${ }^{*}$ Corresponding author \\ efider@chemeng.ntua.gr \\ TEL: $+30-210-7723118$ \\ FAX: $+30-210-7723163$ \\ Received: 30 October 2016; Published online: 18 April 2018 \\ Invited paper from the $4^{\text {th }}$ International ISEKI Food Conference - ISEKI_Food 2016 - Bridging Training and \\ Research for Industry and the Wider Community - Responsible Research and Innovation in the Food Value
}

\begin{abstract}
The objective of this work was to investigate the potential use of pulsed electric field (PEF) in combination with osmotic dehydration (OD) as a pre-freezing step and to evaluate the effect on quality characteristics and shelf life of frozen kiwifruit. Peeled kiwifruit was subjected to PEF $(1.8 \mathrm{kV} / \mathrm{cm})$, sliced and treated in OD-solution (containing glycerol, maltodextrin, trehalose, ascorbic acid, calcium chloride, citric acid, sodium chloride; $\left.1 / 5\left(\mathrm{w}_{\text {fruit }} / \mathrm{w}_{\text {solution }}\right)\right)$ for 30 and $60 \mathrm{~min}$ at $35{ }^{\circ} \mathrm{C}$. Combined, PEF only and OD only treated samples as well as nontreated and blanched $\left(80{ }^{\circ} \mathrm{C}, 60 \mathrm{~s}\right)$ samples were frozen and stored at constant $\left(-5,-10,-15,-25{ }^{\circ} \mathrm{C}\right)$ and dynamic temperature conditions $\left(-18{ }^{\circ} \mathrm{C}-3 \mathrm{~d}\right.$, $\left.-8{ }^{\circ} \mathrm{C}-2.5 \mathrm{~d},-15{ }^{\circ} \mathrm{C}-3 \mathrm{~d}\right)$. Quality of frozen samples was evaluated by means of drip loss, colour, texture, vitamin $\mathrm{C}$ and sensory evaluation (1-9 scale); and shelf life (SL) was calculated. Nontreated and blanched samples presented high drip loss and tissue softening (instrumentally measured as $\mathrm{F}_{\max }$ decrease). The tissue integrity was well retained in all osmotically pretreated samples. PEF pretreatment caused increase of fruit whiteness (increase of $\mathrm{L}$ value) and yellowness (a and/or b value increase); SL calculation was based on colour change. All OD samples had high vitamin content $(24.6 \mathrm{mg} / 100 \mathrm{~g}$ fresh material compared to 138-154 mg/100 g osmodehydrated material); PEF led to $93 \%$ (of the initial) vitamin retention; blanched samples showed the lowest retention (86.9\% of the initial) (criteria for SL calculation). OD and combined PEF-OD treatment increased the shelf life of frozen kiwifruit (up to 3 times; based on sensorial criteria). The developed kinetic models for colour change, vitamin loss, and sensory quality deterioration were validated at dynamic temperature conditions. PEF pretreated OD (at significantly shorter time, $30 \mathrm{~min}$ compared to $60 \mathrm{~min}$ ) kiwifruits retained optimum quality and sensory characteristics. PEF and OD could be used as a preprocessing step of good quality, longer shelf life kiwi sliced frozen products.
\end{abstract}

Keywords: Actinidia deliciosa; Freezing; Pulsed electric field; Osmotic dehydration; Quality; Shelf life

\section{Introduction}

Kiwifruit (Actinidia deliciosa) is an important source of vitamin C, chlorophyll, lutein, 
carotenoids (beta-carotene) and phenolic compounds with high antioxidant capacity. The antioxidant capacity of the fruit is strongly related to the vitamin $\mathrm{C}$ content and the content of phenolic compounds including phenolic acids and flavonoids, and is dependent on the species and cultivar of Actinidia (Leong \& Shui, 2002; Du, Li, Ma, \& Liang, 2009; Latocha, Krupa, Wolosiak, Worobiej, \& Wilczak, 2010; Krupa, Latocha, \& Liwinska, 2011). However, the shelf life of kiwifruit is short and processing should be employed to achieve satisfactory commercial life of kiwi products (Kaya, Aydm, \& Kolayli, 2010; Orikasa et al., 2014). Main quality characteristics of kiwifruit such as colour, firmness and flavour are negatively affected by conventional processing techniques (drying, canning, and freezing and modified atmosphere packaging) (Stanley, Wegrzyn, \& Saleh, 2007). Freezing of kiwifruit leads to significant cellular damage, and subsequent loss of product quality (texture degradation, colour alteration and nutritional loss) (Talens, Escriche, Martinez-Navarrete, \& Chiralt, 2003).

Osmotic dehydration (OD) can be applied as a pretreatment before freezing (dehydrofreezing) to improve and maintain desirable quality characteristics such as colour, flavour and texture, mainly due to the reduction of freezable water and properties of functional impregnated solutes. OD occurs at mild temperatures (up to $50{ }^{\circ} \mathrm{C}$ ) and requires less energy compared to other dehydration methods. OD is achieved by immersion in hypertonic sugar and/or salt solutions of high osmotic pressure/low water activity. Diffusion phenomena take place with two simultaneous counter current flows: a water flow from the food to the outer solution (water loss) and a simultaneous flow of solute from the solution to the plant tissue (solid gain). However, cellular membranes exert a high resistance to mass transfer thus slowing down the OD rate. Various approaches have been reported in the literature (such as pretreatment of the material prior to osmosis, the composition and the concentration of the osmotic solutes in the osmotic solution, the mixing parameters) to influence the rate of diffusion during OD (Rastogi, Eshtiaghi, \& Knorr, 1999; Ferrando \& Spiess, 2001). It is necessary to identify methods which enhance rate of transfers with minimal alteration in quality (Ade-Omowaye, Taiwo, Eshtiaghi, Angersbach, \& Knorr, 2003; Ade-Omowaye, Talens, Angersbach, \& Knorr, 2003).

Among the emerging nonthermal processes of interest, pulsed electric field (PEF) shows promise for inducing cell membrane permeabilisation, called electroporation of food plants (such as apples, carrots, mangos, and red bell peppers). PEF processing is used to increase permeability of the cell membrane and, in the case of expression and extraction, enhances mass transport out of the cells leaving the product matrix largely unchanged (Knorr, Geulen, Grahl, \& Sitzmann, 1994; Knorr \& Angersbach, 1998). Disruption of the cells can be achieved by applying PEF of different intensities (for particular products) across the cell medium or plant tissue (Ade-Omowaye, Taiwo, et al., 2003; AdeOmowaye, Talens, et al., 2003; Amami, Vorobiev, \& Kechaou, 2005, 2006; Lebovka, Bazhal, \& Vorobiev, 2001; Tedjo, Taiwo, Eshtiaghi, \& Knorr, 2002). The mechanism of electropermeabilisation of cell membranes induced by PEF is not yet well elucidated. However, different researchers indicate that the cell walls seem not to be seriously affected by this treatment and the product overall retains its quality (Jemai \& Vorobiev, 2002; Lebovka et al., 2001; Amami et al., 2006). The effect of PEF treatment, preceding OD, on the osmotic behaviour of certain plant tissues has been reported (Ade-Omowaye, Taiwo, et al., 2003; Amami et al., 2005; Parniakov, Bals, Lebovka, \& Vorobiev, 2016). Dermesonlouoglou, Giannakourou, and Taoukis (2016) studied the impact of PEF on mass transfer of osmotically dehydrated kiwifruit.

OD of kiwifruit has been reported in literature, mostly, to describe the structural, and physicochemical changes which occur during the process (Bressa, Dalla Rosa, \& Mastrocola, 1997; Escriche, Garcia-Pinchi, Andres, \& Fito, 2000; Gianotti, Sacchetti, Guerzoni, \& Dalla Rosa, 2001; Cao, Zhang, Mujumdar, Du, \& Sun, 2006; Tocci \& Mascheroni, 2008; Castro-Giraldez, Tylewicz, Fito, Dalla Rosa, \& Fito, 2011; Tylewicz, Fito, Castro-Giraldez, Fito, \& Rosa, 2011; Panarese, Tylewicz, Santagapita, Rocculi, \& Dalla Rosa, 2012). Dehydrofreezing technology has been applied in kiwifruit, and the volatile profile, phe- 
$36 \mid$ Dermesonlouoglou et al.

nolic content and sensory attributes have been studied (Talens et al., 2003; Tylewicz et al., 2011). However, the OD process effect on frozen kiwifruit quality and shelf life through a systematic kinetic analysis of the quality loss has not been reported. Neither has the freezing response of PEF treated plant tissues been studied, nor the combined effect of PEF and OD on frozen kiwifruit quality investigated.

The objective of this study is to investigate the potential use of PEF in combination with OD as a prefreezing step and to evaluate the effect on quality characteristics (drip loss, texture, colour, firmness, vitamin C) and shelf life of frozen kiwifruit. Quality deterioration in the whole temperature range of practical interest (from -5 to $-25^{\circ} \mathrm{C}$ as well as dynamic conditions) was investigated and kinetically modelled.

\section{Materials and Methods}

\subsection{Pulsed electric fields}

Whole peeled kiwifruit "Hayward" was subjected to different PEF process conditions. PEF treatment was conducted in a versatile pilot scale system for food processing (Elcrack-5kW, DIL, Germany). It comprises a pulse generator module and liquid handling system and can also be operated as stand-alone research equipment. Kiwifruits were treated in a $80^{*} 100 * 50$ mm (gap*length*depth), $400 \mathrm{ml}$ volume stainless steel batch chamber for cell disintegration in tap water. The inlet temperature of the chamber was around $20{ }^{\circ} \mathrm{C}$, and the outlet temperature rise due to the PEF treatment did not exceed $5{ }^{\circ} \mathrm{C}$. In the experimental set 250 pulses at field strength intensity of $1.8 \mathrm{kV} / \mathrm{cm}$ (with 15 $\mu$ s pulse width at a frequency of $300 \mathrm{~Hz}$ ) were applied, with average specific energy input of $42.3 \mathrm{~kJ} / \mathrm{kg}$. The selection of PEF conditions was based on a previous comparative study of mass transfer phenomena occurred during subsequent OD by Dermesonlouoglou, Zachariou, Andreou, and Taoukis (2016).

\subsection{Osmotic dehydration}

PEF treated and fresh, non-treated samples were cut into flat discs $(43.5 \pm 0.8 \mathrm{~mm}$ diameter, $6.83 \pm 0.03 \mathrm{~mm}$ thickness), and then partially dehydrated by immersion in a hypertonic solution of glycerol (30\%), high-DE (Dextrose Equivalent) maltodextrin (20\%), trehalose (10\%), ascorbic acid $(2.0 \%)$, calcium chloride $(1.5 \%)$, sodium chloride $(1.0 \%)$ and citric acid $(0.2 \%)(\mathrm{w} / \mathrm{w})$. Glycerol, maltodextrin and trehalose have been used as the main osmotic solutes (Dermesonlouoglou, Giannakourou, \& Taoukis, 2007; Dermesonlouoglou, Zachariou, et al., 2016; Dermesonlouoglou, Pourgouri, \& Taoukis, 2008; Parniakov et al., 2016). Glycerol, a low molecular weight sugar alcohol which is easily digested, non-toxic and recognized as a safe additive (Regulation EC No 1333/2008), is used as a humectant to control aw without $\%$ limitation. Trehalose, a non-reducing dissacharide which is available as a food ingredient and has low sweetness (Treha 16400, Cargill), has been reported to exert a protective role during freezing of membranes and proteins (Ferrando \& Spiess, 2001). The high-DE maltodextrin used (Glucidex, Dehydrated Glucose Syrup 47, Roquette) is an effective osmotic agent which has a very low sweet taste compared to sucrose. The OD solution also comprised citric acid and ascorbic acid to reduce the $\mathrm{pH}$ and hinder extended surface discolouration, calcium chloride to minimize tissue damage during processing, and sodium chloride to enhance mass transfer kinetics as well as to improve the sensory characteristics (particularly to balance the sweet taste) of the final osmodehydrated kiwifruit product (Dermesonlouoglou et al., 2016; Dermesonlouoglou, Zachariou, et al., 2016).

OD treatment was conducted at $35{ }^{\circ} \mathrm{C}(\mathrm{T})$ for 30 (PEFOD1 sample) and $60 \mathrm{~min}$ (PEFOD2 sample) (t). The solution to sample ratio was 5:1(w:w) to avoid significant dilution due to water removal, thereby causing localized reduction of the osmotic driving force during the process. The experimental OD procedure was the same for non-treated (OD) and PEF treated samples (noted as PEFOD1, PEFOD2). Two different types of samples were used as "control" samples: non-treated and blanched by direct immersion of 
Pulsed electric field pretreated osmodehydrofrozen kiwifruit $\mid 37$

samples in hot water at $80{ }^{\circ} \mathrm{C}$ for 60 s (Dermesonlouoglou et al., 2008).

\section{Analysis of physicochemical properties}

Water content $\left(\mathrm{X}_{w}\right)$ and total solids $\left(\mathrm{X}_{s}\right)$ were measured in fresh, blanched and PEF pretreated samples to determine the compositional changes induced by OD. The water loss (WL: g water/g initial dry matter or $\mathrm{g}$ w./i.d.m.) and solid gain (SG: g solids/g initial dry matter or g s./i.d.m.) occurring during OD were calculated (Dermesonlouoglou et al., 2007, 2008). Moisture content was determined gravimetrically after drying at $105{ }^{\circ} \mathrm{C}$ for $24 \mathrm{~h}$ (WTB BINDER 7200, Type E53, Germany). Water activity $\left(\mathrm{a}_{w}\right)$ was monitored (Aqua LAB 4TEV, Decagon Devices, Inc., U.S.A.).

\section{$2.3 \quad$ Freezing}

All samples were quick frozen at $-40{ }^{\circ} \mathrm{C}$ with forced air convection [convection coefficient $\mathrm{h}=11$ $\mathrm{W} / \mathrm{m}^{2} \mathrm{~K}$, Sanyo MIR 553, Sanyo Electric Co, Ora-Gun, Japan], packed in pouches from BOPP-PE laminate film which is used for commercial frozen vegetable products, and kept at this temperature for a short period of time before being distributed to controlled temperature cabinets.

\subsection{Storage and quality loss determination}

Packages of frozen kiwifruit samples were stored in controlled temperature cabinets (Sanyo MIR 153, 253 and 553, Sanyo Electric Co, Ora-Gun, Japan) at constant $\left(-5,-10,-15\right.$ and $-25^{\circ} \mathrm{C}$ used as "control frozen" samples) and dynamic conditions (consisting of several repeated cycles of three isothermal steps $-18{ }^{\circ} \mathrm{C}-3 \mathrm{~d},-8{ }^{\circ} \mathrm{C}-2.5 \mathrm{~d}$, $15{ }^{\circ} \mathrm{C}-3 \mathrm{~d}$ ) in temperature programmable control cabinets monitored by type $\mathrm{T}$ thermocouples (CR10X,Campbell Scientific, UK).

Selected quality parameters (drip loss, texture, colour, vitamin $\mathrm{C}$, and sensory characteristics) were evaluated at appropriate time intervals (Constant conditions $-5^{\circ} \mathrm{C}: 8,16,29,41,57$ days;
$-10{ }^{\circ} \mathrm{C}: 8,29,57,100,132,176,201,258$ days; $-15{ }^{\circ} \mathrm{C}: 16,41,57,100,176,258$ days; Dynamic conditions: $16,41,57,111,158,213$ days) in order to model their rate of change versus storage time at all constant temperatures.

\section{Drip loss}

Frozen slices were each put into a covered tare $100 \mathrm{ml}$ beaker which were defrosted for $24 \mathrm{~h}$ at 4 ${ }^{\circ} \mathrm{C}$, put on a sieve for $15 \mathrm{~min}$ to allow the excess water to drip off and were weighed to measure the drip loss of the kiwifruit slices during thawing (Talens et al., 2003). Triplicates of all the differently treated slices were determined.

\section{Texture}

Texture (at least eight sampling times per treatment) of kiwifruit was determined with a texture analyzer (TA-XT2i of Stable Micro Systems, England). The test was performed on a non-lubricated flat platform, using a knife probe, where the samples were cut at a fixed rate $(0.5 \mathrm{~mm} / \mathrm{s})$ and depth $(1 / 3$ of the initial $)$. The maximum peak force $\left(\mathrm{F}_{\max }, \mathrm{N}\right)$ was the mechanical parameter considered, and was expressed as firmness. Triplicates of all the differently treated slices were measured at each sampling time.

\section{Colour}

Quantification of the colour change was based on measurement of CIELab values (L: illuminance; a: red saturation index; b: yellow saturation index) (CIE, 1978) using a hand-held dual-function reflected-light CR-200 Minolta Chromameter ${ }^{\circledR}$ with diffuse illumination $/ 0^{\circ}$ viewing angle (Minolta Co., Japan). Three replicates of each measurement were conducted on the uniform green part of ten kiwifruit samples after thawing. Instrumentally measured colour was found to be adequately described by total colour change $\Delta E=$ $\sqrt{\left(L-L_{0}\right)^{2}+\left(a-a_{0}\right)^{2}+\left(b-b_{0}\right)^{2}}$, where $\mathrm{L}_{0}$, $\mathrm{a}_{0}$ and $\mathrm{b}_{0}$ values are $\mathrm{L}$, a and $\mathrm{b}$ values measured at zero storage time. 


\section{Vitamin C}

Vitamin C (L-ascorbic acid) was determined using a high performance liquid chromatography method previously detailed in Giannakourou and Taoukis (2003). The results were expressed in mg L-ascorbic acid $/ 100 \mathrm{~g}$ fresh material (f.m.) or osmodehydrated material and plotted versus time. All measurements were conducted in duplicate.

\section{Sensory attribute}

Trained assessors were chosen for the assessment of the sensory attributes of kiwifruit samples (International Organization for Standardization, 2012). Assessors (8 members of the trained sensory panel; female 5 and male 3 ; ages 22-44) were asked to score for overall visual appearance, overall texture (including firmness, consistency, juiciness), flavour and overall acceptability of kiwifruit samples, in appropriate forms with descriptive terms reflecting the organoleptic evolution of quality deterioration. Rating was assigned separately for each parameter on a 1-9 descriptive intensity scale (9 being the highest quality score and 1 the lowest) (Lim, 2011; Dermesonlouoglou et al., 2008, 2016; Tsironi, Dermesonlouoglou, Giannakourou, \& Taoukis, 2009).

\subsection{Statistical analysis}

Analysis of variance (ANOVA) and Tukey multiple range tests $(\alpha=0.05)$ were used to determine statistically significant differences (STATISTICA ${ }^{\circledR}$ ) between the different storage temperatures and treatments, concerning physico-chemical parameters, the rates of colour change, vitamin $\mathrm{C}$, and sensory quality loss.

\section{Results and Discussion}

\subsection{Pulsed electric fields and osmotic dehydration}

In Table 1, physico-chemical parameters (initial water content $\mathrm{X}_{W}$, water activity $\mathrm{a}_{W}, \mathrm{pH}$, water loss-WL, and solid gain-SG) of kiwifruit slices before and after blanching, PEF and/or OD processing are presented. The OD pretreatment caused a decrease in the water content $(\mathrm{p}<0.05)$, $\mathrm{pH}$ and water activity, with a corresponding increase in the total solids. The application of blanching as well as PEF processing did not significantly change the level of water, total solids, $\mathrm{pH}$ and $\mathrm{a}_{W}(\mathrm{p}>0.05)$.

During OD pretreatment, a high rate of mass exchange was achieved. The water loss (WL) and solid gain (SG) values for OD time 30 and $60 \mathrm{~min}$ were calculated as 1.78 and $1.99 \mathrm{~g}$ w./g i.d.m., and 0.208 and $0.248 \mathrm{~g} \mathrm{s./g}$ i.d.m., respectively. Application of PEF significantly enhanced the rate of transfers during OD. WL was calculated as 1.68 and $2.37 \mathrm{~g} \mathrm{w} . / \mathrm{g}$ i.d.m. for OD time 30 and $60 \mathrm{~min}$ (PEFOD1 and PEFOD2 samples), respectively, and $\mathrm{SG}$ as 0.550 and $0.636 \mathrm{~g} \mathrm{~s} / \mathrm{g}$ i.d.m. for OD time 30 and $60 \mathrm{~min}$ (PEFOD1 and PEFOD2 samples), respectively.

Osmotic pretreatment substantially lowered $\mathrm{a}_{w}$ to a level of 0.89(PEFOD2)-0.92(PEFOD1 \& OD samples) (compared to 0.95 for non-pretreated samples), mainly due to the hypertonic solution ingredients used in this particular case. The final aw value for PEFOD processing was achieved at the shorter OD time. 30 min OD time for PEF pretreated samples was found to be equivalent to 60 min OD time.

\subsection{Quality loss determination at isothermal conditions}

\section{Drip loss and texture}

In Figs $1(\mathrm{a}$ and $\mathrm{b})$ the drip loss and firmness values for non-treated, blanched, OD, PEF, and PEF pretreated OD kiwifruit samples stored at isothermal temperature conditions $\mathrm{T}=-15{ }^{\circ} \mathrm{C}$, and non-isothermal conditions $\mathrm{T}_{\text {eff }}=-13.3{ }^{\circ} \mathrm{C}$ (representatively) were demonstrated. Nontreated and PEF pre-treated samples suffered from higher drip loss and tissue softening at zero storage time. Respective values, measured at zero storage time for all kiwifruit samples were presented in Table 2. The tissue integrity was retained with storage time for all osmotically pretreated, combined with PEF (PEFOD2 and PEFOD1) or not, samples (low drip loss showing a decrease with storage time and increased firmness not showing any clear tendency). On the 
Pulsed electric field pretreated osmodehydrofrozen kiwifruit $\mid 39$

Table 1: Physico-chemical parameters of kiwifruit slices before and after blanching, PEF and/or OD processing

\begin{tabular}{cccccc}
\hline Sample & $\begin{array}{c}\mathbf{X}_{w} \\
\text { (g w/g i.f.m.) }\end{array}$ & $\mathbf{a}_{w}$ & $\mathbf{p H}$ & $\begin{array}{c}\mathbf{W L} \\
\text { (g w./g i.d.m.) }\end{array}$ & $\begin{array}{c}\text { SG } \\
\text { (g s./g i.d.m.) }\end{array}$ \\
\hline Non & $0.858 \pm 0.003 \mathrm{a}$ & $0.951 \pm 0.014 \mathrm{a}$ & $3.39 \pm 0.18 \mathrm{ab}$ & - & - \\
OD & $0.765 \pm 0.007 \mathrm{~b}$ & $0.927 \pm 0.018 \mathrm{a}$ & $3.28 \pm 0.09 \mathrm{~b}$ & $1.99 \mathrm{a}$ & $0.248 \mathrm{a}$ \\
blanched & $0.862 \pm 0.011 \mathrm{a}$ & $0.955 \pm 0.017 \mathrm{a}$ & $3.42 \pm 0.11 \mathrm{ab}$ & - & - \\
PEF & $0.856 \pm 0.010 \mathrm{a}$ & $0.947 \pm 0.016 \mathrm{a}$ & $3.53 \pm 0.07 \mathrm{a}$ & - & - \\
PEFOD1 & $0.740 \pm 0.006 \mathrm{~b}$ & $0.923 \pm 0.022 \mathrm{ab}$ & $3.30 \pm 0.06 \mathrm{~b}$ & $1.68 \mathrm{~b}$ & $0.550 \mathrm{~b}$ \\
PEFOD2 & $0.684 \pm 0.005 \mathrm{c}$ & $0.892 \pm 0.048 \mathrm{~b}$ & $3.27 \pm 0.11 \mathrm{~b}$ & $2.37 \mathrm{c}$ & $0.636 \mathrm{~b}$ \\
\hline
\end{tabular}

\pm represent standard deviation of triplicates. Different superscript letters indicate significantly different means $(\mathrm{p}<0.05)$ within a column (differences between treatments)

other hand, blanched samples showed high drip loss and increased firmness compared to nontreated and PEF pretreated samples. Blanching pretreatment seemed to protect partially kiwifruit from tissue collapse.

The influence of fruit firmness on kiwifruit acceptability is significant. The firmness of a kiwifruit strongly influences its sensory quality at the moment of consumption, influencing the perception of aroma intensity, sweetness, acidity and ripeness. It has been reported that fruits with softer core are perceived as having a more intense flavour, a more sweet and fruity taste and stronger ripe fruit characteristics (Stec, Hodgson, Macrae, \& Triggs, 1989). Osmodehydrated kiwifruits with firmness values $>0.5 \mathrm{~N}$ (up to $1.5 \mathrm{~N}$ ) were characterized as "not soft", and at the same time as "having a more intense flavour, and a more sweet taste (acceptable and desirable)" according to sensory analysis conducted (data not shown). All OD treated kiwifruit samples presented increased firmness compared to nontreated ones showing that one of the main goals of the application of the osmotic dehydration had been achieved. Delicate plant tissues, with high water content (such as cucumber, strawberry), treated by osmotic dehydration have been reported to have improved texture characteristics (Dermesonlouoglou et al., 2008, 2016). PEF application caused a significant decrease in firmness. All PEF treated OD samples (compared to OD samples) had lower firmness values at zero storage time leading to softer fruit tissue. Firmness values increased with OD time (from 30 to
60 min) for PEF pretreated OD samples (from PEFOD1 to PEFOD2 sample). However, the effect of applied pretreatments of PEF and OD on kiwifruit texture (drip loss and firmness) could not be mathematically modelled.

\section{Colour}

Colour is an important quality index for freshcut kiwifruit products. Fresh kiwifruit is characterized by the green colour of its flesh. The colour changes in kiwifruit during ripening (towards more yellowness and less greenness) are due to the loss of chlorophylls which no longer mask the carotenoids (Montefiori, McGhie, Hallett, \& Costa, 2009).

The results of this study showed that the colour of kiwifruits was significantly different immediately after the application of PEF pretreatment. In PEF and blanched pretreated OD kiwifruits, L- and a-values were higher, but b- values did not show significant differences at the zero storage time. Respective values, measured at zero storage time for all kiwifruit samples are presented in Table 2. The effect of PEF and blanching on colour, compared to non-treated kiwifruit was an increase in fruit lightness (L increase) and a decrease in green colour (a increase; b did not show significant differences). The PEF effect on OD treated kiwifruit colour was an increase in fruit lightness (L increase), and a decrease in yellow colour (b decrease; a did not show significant differences).

The total colour change of all kiwifruit samples during storage was expressed by $\Delta \mathrm{E}$ values. The 
$40 \mid$ Dermesonlouoglou et al.
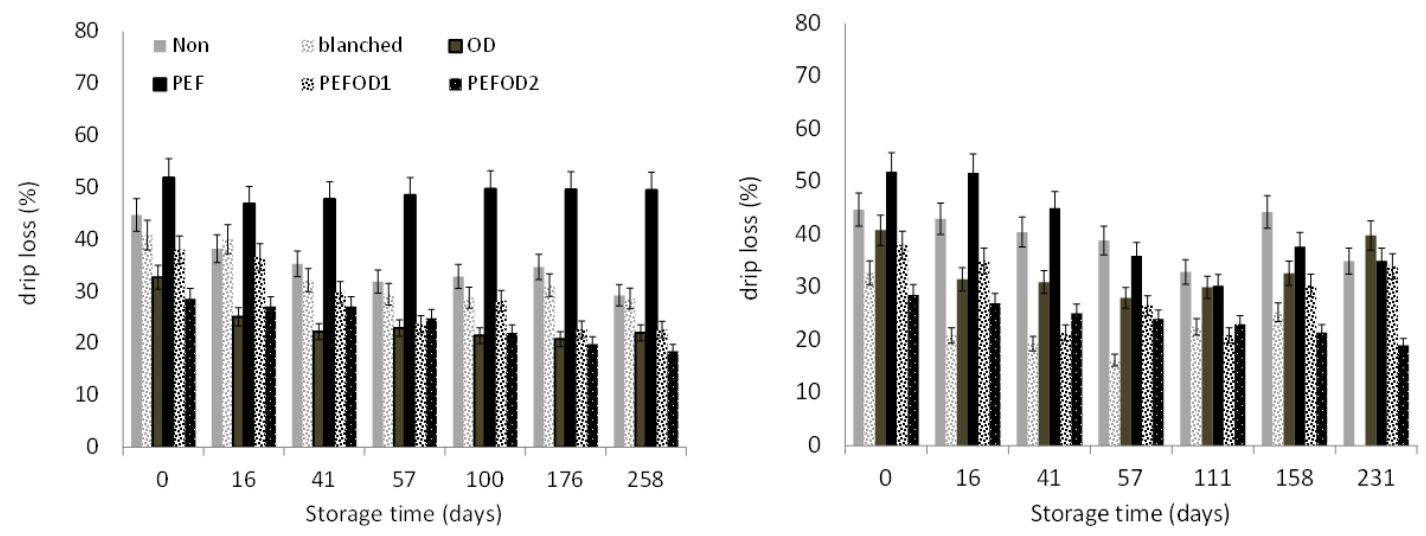

(a1)

(a2)
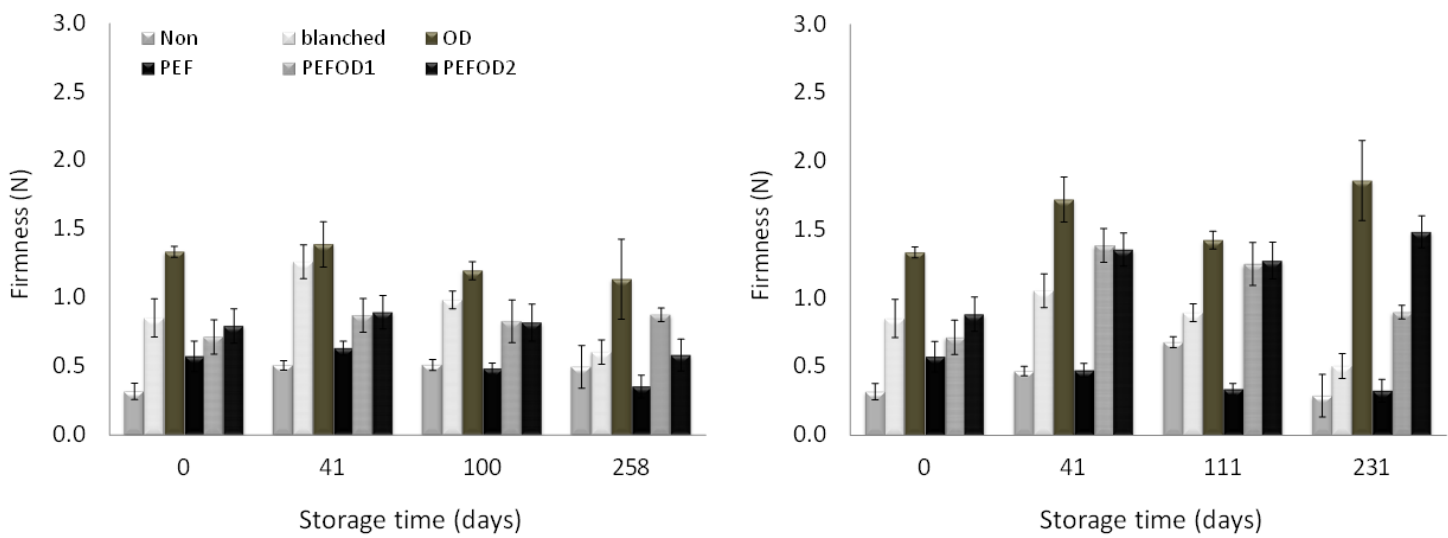

(b1)

(b2)

Figure 1: (a) Drip loss (\%), and (b) firmness $\left(\mathrm{F}_{\max }, \mathrm{N}\right)$ versus time t for non pretreated, blanched, OD, PEFOD1-, PEFOD2-pretreated kiwifruit slices stored at constant temperature conditions $\mathrm{T}=-15{ }^{\circ} \mathrm{C}$ (index 1), and dynamic conditions $\mathrm{T}_{\text {eff }}=-13.3{ }^{\circ} \mathrm{C}$ (index 2) (error bars indicate the standard deviation from replicates) 
Pulsed electric field pretreated osmodehydrofrozen kiwifruit $\mid 41$

Table 2: Quality parameters of kiwifruit slices before and after blanching, PEF and/or OD processing

\begin{tabular}{|c|c|c|c|c|c|}
\hline Sample & $\begin{array}{l}\text { Drip loss } \\
(\%)\end{array}$ & $\begin{array}{l}\text { Firmness } \\
(\text { Fmax, N) }\end{array}$ & $\begin{array}{l}\text { Colour } \\
(\mathrm{L0}-, \text { a0-, b0- } \\
\text { values })\end{array}$ & $\begin{array}{c}\text { Sensory scores for } \\
\text { colour, texture, } \\
\text { flavour, overall impression }\end{array}$ & $\begin{array}{l}\text { Vitamin } \mathrm{C} \\
\text { (mg/100 } \mathrm{g} \text { f.m. } \\
\text { or OD.m.) }\end{array}$ \\
\hline Non & $44.7 \pm 5.2 \mathrm{a}$ & $0.32 \pm 0.06 \mathrm{a}$ & $\begin{array}{l}42.46 \pm 0.66 \mathrm{a} \\
-9.25 \pm 0.53 \mathrm{a} \\
21.63 \pm 1.67 \mathrm{a}\end{array}$ & $\begin{array}{c}\text { 7.3ab, 6.5a, } \\
\text { 7.0a, 6.5ab }( \pm 0.5)\end{array}$ & $24.6 \pm 2.4 \mathrm{a}$ \\
\hline OD & $32.7 \pm 3.0 \mathrm{~b}$ & $1.33 \pm 0.04 \mathrm{~d}$ & $\begin{array}{l}44.39 \pm 1.28 \mathrm{ab} \\
-8.91 \pm 1.10 \mathrm{ab} \\
22.47 \pm 2.62 \mathrm{a}\end{array}$ & $\begin{array}{c}8.0 \mathrm{~b}, 8.0 \mathrm{bc} \\
7.5 \mathrm{a}, 7.5 \mathrm{~b}( \pm 0.3)\end{array}$ & $138 \pm 11 b$ \\
\hline blanched & $40.8 \pm 4.2 \mathrm{a}$ & $0.85 \pm 0.01 \mathrm{c}$ & $\begin{array}{c}47.50 \pm 5.44 \mathrm{bc} \\
-7.97 \pm 0.95 \mathrm{bc} \\
22.01 \pm 0.11 \mathrm{a}\end{array}$ & $\begin{array}{c}6.0 \mathrm{c}, 6.0 \mathrm{a} \\
6.5 \mathrm{ab}, 6.0 \mathrm{c}( \pm 0.3)\end{array}$ & $22.9 \pm 3.2 \mathrm{a}$ \\
\hline PEF & $51.9 \pm 4.8 \mathrm{c}$ & $0.57 \pm 0.04 \mathrm{~b}$ & $\begin{array}{l}48.49 \pm 1.79 \mathrm{~cd} \\
-7.00 \pm 0.60 \mathrm{c} \\
21.80 \pm 2.50 \mathrm{a}\end{array}$ & $\begin{array}{c}5.8 \mathrm{c}, 5.8 \mathrm{a} \\
5.5 \mathrm{~b}, 6.0 \mathrm{c}( \pm 0.2)\end{array}$ & $21.4 \pm 2.8 \mathrm{a}$ \\
\hline PEFOD1 & $38.4 \pm 3.1 \mathrm{ab}$ & $0.72 \pm 0.08 \mathrm{c}$ & $\begin{array}{c}54.91 \pm 0.11 \mathrm{e} \\
-8.25 \pm 0.29 \mathrm{ab} \\
31.98 \pm 0.08 \mathrm{~b}\end{array}$ & $\begin{array}{c}\text { 7.5ab, } 7.5 \mathrm{c} \\
\text { 7.0a, 7.0ab }( \pm 0.4)\end{array}$ & $140 \pm 9 \mathrm{~b}$ \\
\hline PEFOD2 & $28.5 \pm 2.8 \mathrm{~b}$ & $0.79 \pm 0.08 \mathrm{c}$ & $\begin{array}{l}51.42 \pm 0.89 \mathrm{~d} \\
-6.95 \pm 0.62 \mathrm{c} \\
28.83 \pm 0.59 \mathrm{~b}\end{array}$ & $\begin{array}{c}7.5 \mathrm{ab}, 7.3 \mathrm{c} \\
7.0 \mathrm{a}, 7.5 \mathrm{~b}( \pm 0.4)\end{array}$ & $154 \pm 13 \mathrm{~b}$ \\
\hline
\end{tabular}

\pm represent standard deviation of triplicates. Different superscript letters indicate significantly different means $(\mathrm{p}<0.05)$ within a column (differences between treatments)

normalized version of $\Delta \mathrm{E}$ (describing the exponential decrease of $\frac{\Delta E_{\max }-\Delta E}{\Delta E_{\max }}$ as follows) has been preferred so as to better show the comparative effect of the different osmotic pretreatments on the rate of colour change, and also to the best fit the experimental data (Eq. 1):

$$
\frac{\Delta E_{\max }-\Delta E}{\Delta E_{\max }}=\exp \left(-k_{\text {colour }}{ }^{t}\right)
$$

where, $\Delta E$ is the $\Delta E$-value after storage time $t$ (days), $\Delta E_{\max }$ is the asymptotic value of $\Delta \mathrm{E}$ value observed after a period of storage, defined as $\Delta E_{\max }=6.0$, for non-treated and blanched samples, 8.0 for OD samples, and 10.0 for PEF, PEFOD1, and PEFOD2 samples, and $k_{\text {colour }}$ the apparent rate of colour deterioration $\left(\right.$ days $^{-1}$ ). The temperature dependence of colour change was described by the Arrhenius Equation (Eq. 2):

$$
\ln k=\ln k_{r e f}-\left(\frac{E_{a}}{R}\right)\left(\frac{1}{T}-\frac{1}{T_{r e f}}\right)
$$

where, $k_{r e f}$ is the reaction rate constant at a reference temperature $\left(\right.$ days $^{-1}$ ) $T_{\text {ref }}(\mathrm{K})$ (in this study $\left.-18{ }^{\circ} \mathrm{C}\right), E_{a}$ the activation energy of the estimated action $(\mathrm{J} / \mathrm{mol})$ and $R$ the universal gas constant $(\mathrm{J} / \mathrm{mol} \cdot \mathrm{K})$.

In Figs 2(a1 and a2), the colour change (calculated using Eq. 1) for non-treated, blanched, OD and PEF pretreated OD kiwifruit samples stored at isothermal temperature conditions $\mathrm{T}=-$ $15{ }^{\circ} \mathrm{C}$, and non-isothermal conditions $T e f f=-13.3$ ${ }^{\circ} \mathrm{C}$ (representatively) are presented. PEF pretreatment accelerated the increase in lightness $(\mathrm{L}$ value increase) and yellowness (a value increase and/or b value increase), at zero storage time as well as during storage (data not shown). Increasing $\mathrm{L}$, a and b values respectively indicate an increase in fruit lightness or whiteness, a decrease in green colour, and an increase in yellow colour. For example, L, a, b values of non pretreated and pretreated kiwifruit samples stored at $-10{ }^{\circ} \mathrm{C}$ for two different representative storage times were measured as Non: 47.48, -7.63, 18.81; OD: 45.03, -7.82, 22.70; PEF: 50.36, -6.95, 26.89; PEFOD1: 50.80, -7.11, 23.83; PEFOD2: 48.21, -5.95, 24.34, for 29 days, and Non: 43.84, -3.61, 16.42; OD: 43.61, -3.96, 24.00; PEF: 53.45, -6.05, 27.12; PE- 
FOD1: 52.86, -6.31, 29.03; PEFOD2: 52.59, 6.91 , 28.55, for 176 days. PEF treated samples showed the highest colour change rate values $k_{\text {colour }}$ at all temperatures studied, followed by non-treated, blanched and OD treated samples (the last two showed similar colour change rates). On the other $\mathrm{PEF}$ pretreated OD samples had lower $k_{\text {colour }}$ values which positively affected the colour change of osmodehydrated kiwifruit tissue. Activation energy $E_{a}$ values ranged from 77.49(PEF sample) to 97.77 (Non-treated sample) $\mathrm{kJ} / \mathrm{mol}$ (Table 3).

\section{Vitamin C}

Vitamin $\mathrm{C}$ content is the most important nutritional attribute of kiwifruit (Du et al., 2009). In this study, the zero storage time vitamin $\mathrm{C}$ content of kiwifruit was measured to be $24.6 \mathrm{mg} / 100$ g f.m. (Table 2: Respective values, measured at zero storage time for all kiwifruit samples). The vitamin $\mathrm{C}$ retention for $\mathrm{PEF}$ and blanched pretreated kiwifruit samples were $93.0 \%$ and $86.9 \%$ of the zero storage time values, respectively. The vitamin $\mathrm{C}$ retention of osmotically dehydrated red bell peppers was reported to vary from 89.6 to $96.5 \%$. Those samples subjected to 50 pulses, at a field strength of $2 \mathrm{kV} / \mathrm{cm}$, had the least retention whilst those treated with 1 pulse, at the same field strength, had the highest retention according to Ade-Omowaye, Talens, et al. (2003). During OD, the vitamin C increased to 138 $\mathrm{mg} / 100 \mathrm{~g}$ osmodehydrated material (at OD time $60 \mathrm{~min})$. For PEF pretreated samples, the vitamin $\mathrm{C}$ content of osmodehydrated samples varied from 140 to $154 \mathrm{mg} / 100 \mathrm{~g}$ osmodehydrated material (at OD time 30 and $60 \mathrm{~min}$ ). In this study, the vitamin $\mathrm{C}$ increase observed during osmotic dehydration is due to the enrichment of the osmotic solution with ascorbic acid. This increase was more pronounced for longer OD times and with PEF pretreatment. Ade-Omowaye, Taiwo, et al. (2003), Ade-Omowaye, Talens, et al. (2003) reported improved mass transfer during drying as a consequence of PEF pretreatment and suggested minimal loss of vitamin $\mathrm{C}$ due to electric field treatment (red bell peppers, $2 \mathrm{kV} / \mathrm{cm}, 1-50$ pulses). Taiwo, Angersbach, Ade-Omowaye, and Knorr (2001) reported that using field strengths $>1.0 \mathrm{kV} / \mathrm{cm}$ depleted the vitamin content. All the PEF treated samples had vitamin $\mathrm{C}$ content lower than the nontreated due to faster leaching (as a result of permeabilized cells) into osmotic solution.

In Figs 2(b1 and b2) the vitamin C loss for nontreated, blanched, OD and PEF pretreated OD kiwifruit samples stored at isothermal temperature conditions $\mathrm{T}=-15{ }^{\circ} \mathrm{C}$, and non-isothermal temperature conditions $\mathrm{T}_{\text {eff }}=-13.3^{\circ} \mathrm{C}$ (representatively) are shown. Vitamin $\mathrm{C}$ content change with storage time was mathematically described by a first-order reaction as follows (Eq. 3).

$$
\frac{C_{v i t C}}{C_{v i t C 0}}=\exp \left(-k_{v i t C} t\right)
$$

where, $C_{v i t C}$ is the vitamin $\mathrm{C}$ concentration (mg/g initial dry mass) at time t, $C_{v i t C, 0}$ is the initial concentration of vitamin $\mathrm{C}$, and $k_{v i t C}$ is the reaction rate constant. The temperature dependence of colour deterioration was described by the Arrhenius equation (Eq. 2). OD and/or $\mathrm{PEF}$ pretreated kiwifruit samples gave the lowest $k_{v i t C}$ values, whilst PEF, blanched and nontreated samples gave the highest ones. Activation energy $E_{a}$ values, calculated by Eq. 2, varied from 59.45 to $67.78 \mathrm{~kJ} / \mathrm{mol}$ for the pretreated samples. The larger $E_{a}$ value, $81.16 \mathrm{~kJ} / \mathrm{mol}$ calculated for the non-treated samples indicates the rate of vitamin $\mathrm{C}$ loss has a higher dependence on temperature change compared to pretreated samples (Table 4).

\section{Sensory attributes}

The descriptive tests for kiwifruit samples showed significant effects of the osmotic pretreatment. Based on results, blanched and PEF pretreated frozen samples compared to non-treated samples suffered from detrimental texture, colour and flavour deterioration at zero storage times and during their storage. The tissue integrity was well retained for osmotically pretreated samples, followed by PEF pretreated samples (PEFOD1 and PEFOD2). PEF pretreated samples were characterized by a colour change (green to yellow). Flavour and taste of all pretreated samples were judged as "pleasant and acceptable" despite differing from the fresh kiwifruit characteristics. The pretreated samples were preferred in all attributes, including taste, and they showed

\begin{tabular}{l|l|l|l} 
IJFS & April 2018 & Volume 7 & pages 34-51
\end{tabular} 
Pulsed electric field pretreated osmodehydrofrozen kiwifruit $\mid 43$

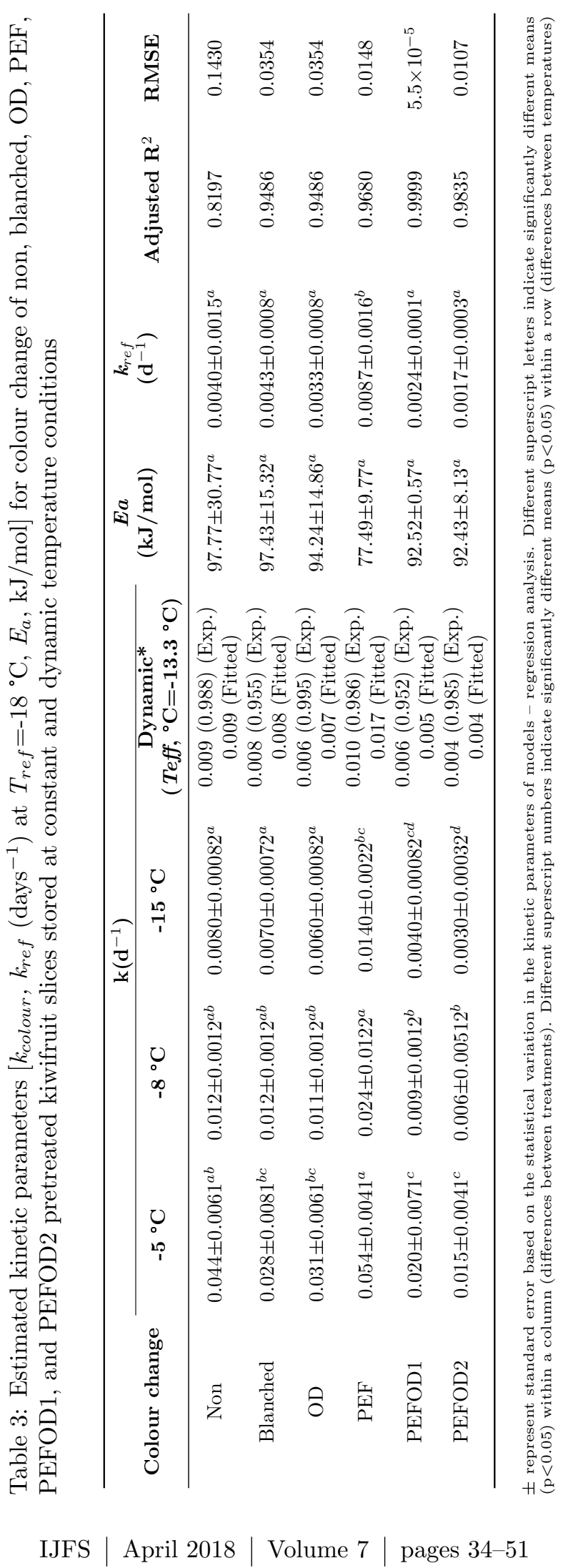


44 | Dermesonlouoglou et al.
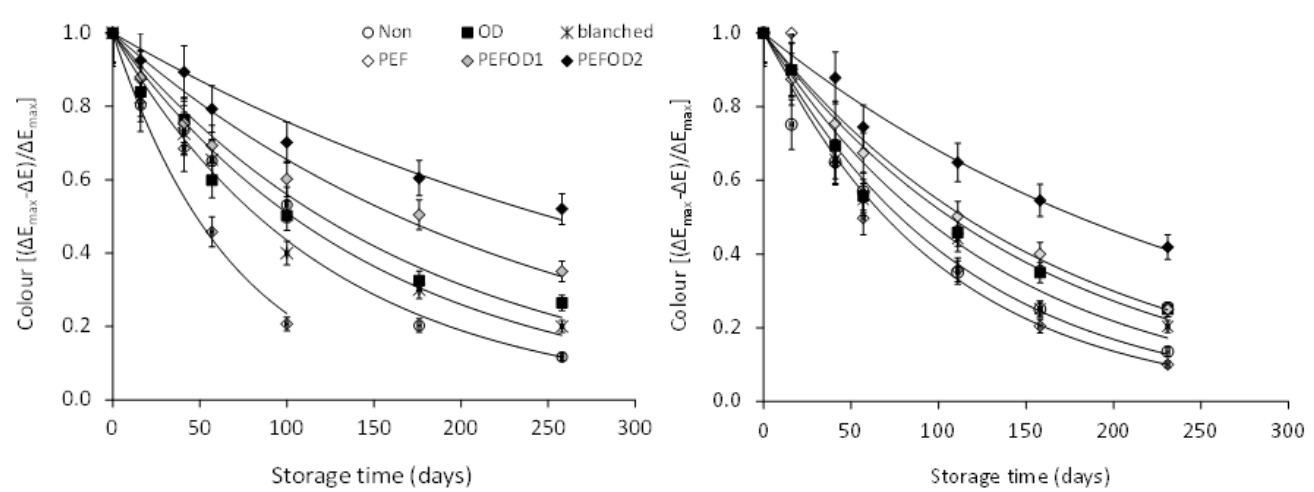

(a1)

(a2)
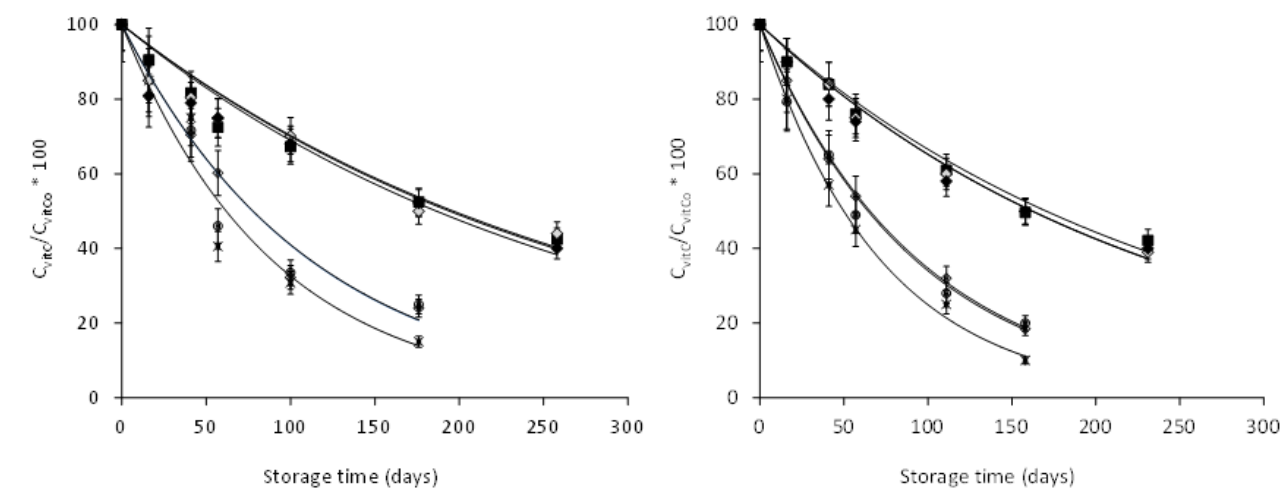

(b1)

(b2)
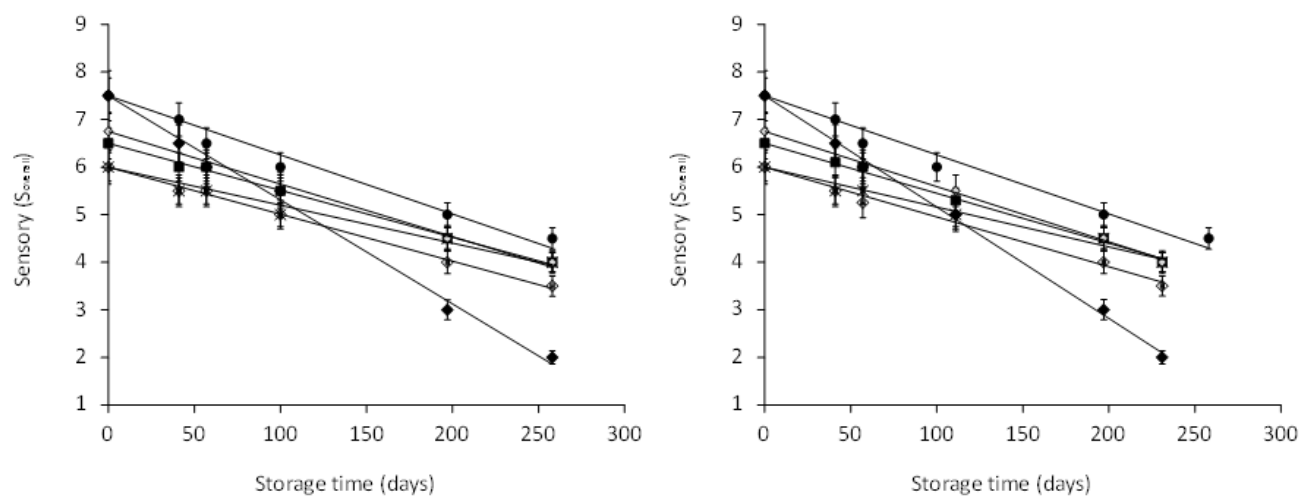

(c1)

(c2)

Figure 2: (a) Colour $\left[\left(\Delta E_{\max }-\Delta E\right) /\left(\Delta E_{\max }\right)\right]$, (b) vitamin $\mathrm{C}\left(C_{v i t C}, \mathrm{mg} / 100 \mathrm{~g}\right)$, and (c) sensory quality (scoring for overall quality, $S_{\text {overall }}$ ) versus time t for non pretreated, blanched, OD-, PEFOD1-, PEFOD2-pretreated kiwifruit slices stored at isothermal temperature conditions $\mathrm{T}=-15{ }^{\circ} \mathrm{C}$ (index 1 ), and nonisothermal conditions $\mathrm{T}_{e f f}=-13.3{ }^{\circ} \mathrm{C}$ (index 2) (lines represent the first and zero order fit, respectively and error bars indicate the standard deviation from replicates) 
Pulsed electric field pretreated osmodehydrofrozen kiwifruit $\mid 45$
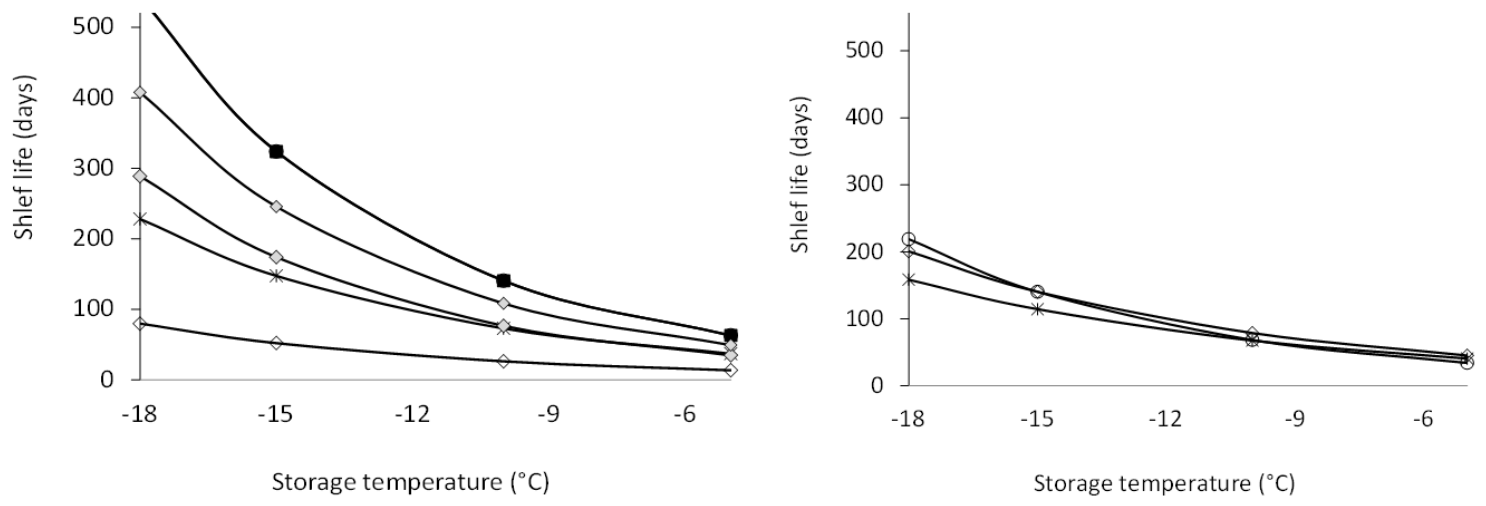

(a)

(b)

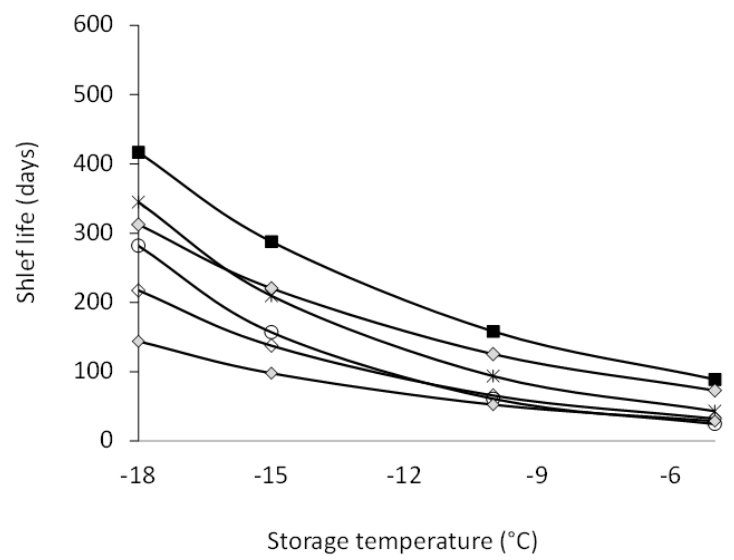

(c)

Figure 3: Shelf life $(S L, \mathrm{~d})$ non, blanched, OD, PEF, PEFOD1, and PEFOD2 pretreated kiwifruit slices stored at isothermal and non-isothermal temperature conditions based on (a) colour $\left(\left(\Delta E_{\text {final }}=5\right)\right.$, (b) vitamin $\mathrm{C}\left(\mathrm{C}_{\text {vitC, final }}=0.30 *\left(C_{v i t C, 0}\right.\right.$, samples: non, blanched and PEF pretreated $)$ and $(\mathrm{c})$ sensory evaluation $\left(\left(S_{\text {overall }, \text { final }}=5.0 / 9.0\right)\right.$ 
46 | Dermesonlouoglou et al.

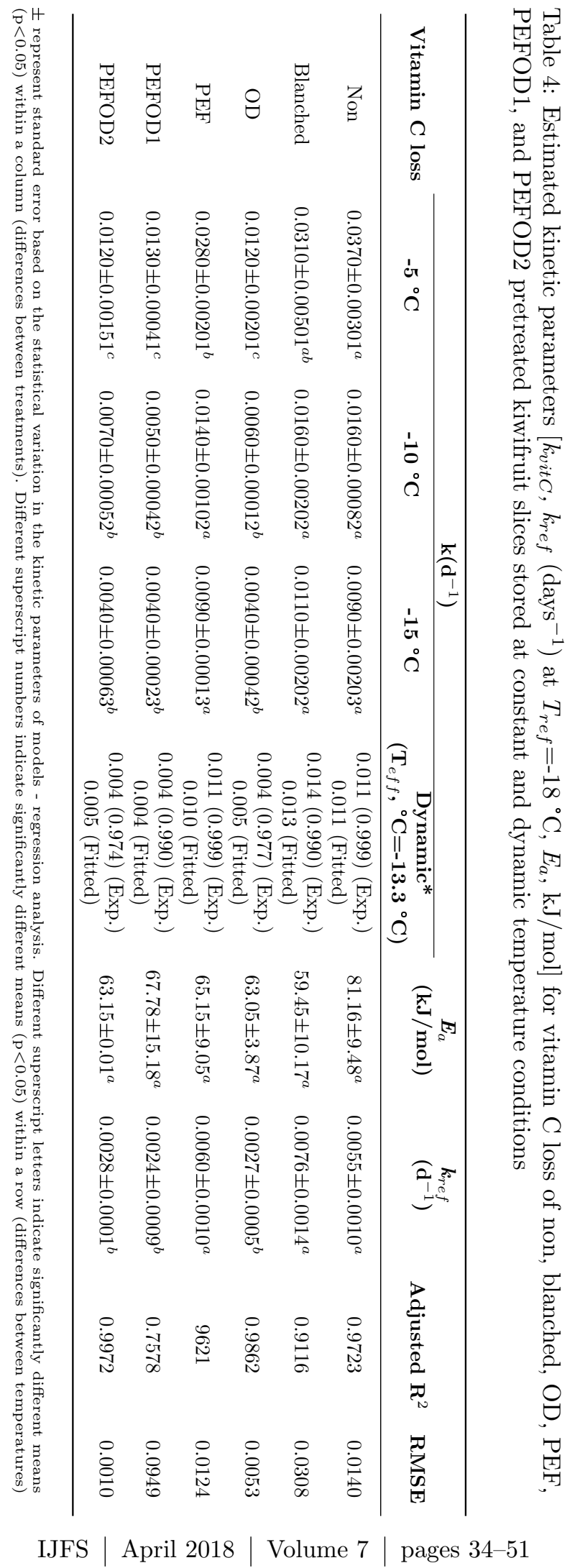


an increased stability with storage.

The scores for the selected sensory properties (colour, texture, flavour-data not shown; Respective values, measured at zero storage time for all sensory properties were presented in Table 2) as well as overall sensory quality during storage were kinetically modelled using zero-order reaction kinetics (Eq. 4).

$$
S=S_{0}-k_{\text {sensory }} t
$$

where, $S$ and $S o$ are the scores for sensory attributes evaluated at time $\mathrm{t}$ and zero respectively (Table 2) and $k_{\text {sensory }}$ the apparent rate of quality deterioration based on sensory evaluation $\left(\right.$ days $\left.^{-1}\right)$. The temperature dependence of colour deterioration was described by the Arrhenius equation (Eq. 2).

In Figs 2(c1 and c2) the scores for the overall sensory quality versus time for non-treated, blanched, OD and PEF pretreated OD kiwifruit samples stored at isothermal temperature conditions $\mathrm{T}=-15{ }^{\circ} \mathrm{C}$, and non-isothermal temperature conditions $\mathrm{T}_{\text {eff }}=-13.3{ }^{\circ} \mathrm{C}$ are representatively shown. Kiwifruit samples gave similar $k_{\text {sensory }}$ values. However, scores at time zero $S_{0}$ were higher for pretreated samples [7.5(OD), 7.25(PEFOD2), 7.0(PEFOD1), 6.5(non-treated), 6.0(blanched and PEF)]. $E_{a}$ values varied from 79.39 (PEFOD1 sample) to 109.32(blanched sample) kJ/mol (Table 5).

\subsection{Shelf life determination}

The end of shelf life for all samples was correlated to colour change, $\Delta \mathrm{E}_{\text {final }}=5$, vitamin $\mathrm{C}$ retention, $\mathrm{C}_{v i t C \text {, final }}=0.30^{*} \mathrm{C}_{\text {vitC }, 0}$, and sensory scoring $\mathrm{S}_{\text {overall, final }}=5.0 / 9.0$. Based on these limits, indicating the end of shelf-life, the Arrhenius equation (Eq. 2) can be combined with Equations 1, 3, and 4 to develop predictive models that allow shelf-life determination at any temperature, based either on colour change (Eq. 1) or vitamin C retention (Eq. 3) or sensory scoring (Eq. 4). The shelf life values calculated for temperatures from -5 to $-18{ }^{\circ} \mathrm{C}$ are shown in Figs. $3(\mathrm{a}, \mathrm{b}$ and $\mathrm{c})$. The rejection of non-treated, PEF and PEFOD1 samples was mainly due to instrumentally measured colour loss. The instrumentally measured colour loss was well correlated with the sensory evaluation of colour, especially at low temperatures $<-15{ }^{\circ} \mathrm{C}$ (data not shown). The rejection of OD and PEFOD2 samples was due to the sensory scoring for the overall quality of the final kiwifruit product, and taking into account the scoring for all studied sensory characteristics. As far as the blanched kiwifruit samples were concerned, the shelf life determining criteria was found to be the vitamin $\mathrm{C}$ retention. Based on the above mentioned criteria for each sample, the shelf life at the reference temperature of $-18{ }^{\circ} \mathrm{C}$ could be calculated: 79 days for PEF, 158 days for blanched, 173 days for non-treated, 211 days for PEFOD2, 288 days for PEFOD1, 378 days for OD samples. The respective shelf life values at $-10{ }^{\circ} \mathrm{C}$ were: 26 days for PEF, 40 days for blanched, 44 days for non-treated, 76 days for PEFOD1, 125 days for PEFOD2, and 158 days for OD samples. According to results, the application of osmotic dehydration and $\mathrm{PEF}$ pretreatments significantly increased the stability of kiwifruit slices during their frozen storage.

\subsection{Validation of the predictive models in dynamic conditions}

To demonstrate the integrated effect of the temperature variability on quality, the term, effective temperature $\mathrm{T}_{\text {eff }}$ is introduced $\left(\mathrm{T}_{\text {eff }}=-13.3{ }^{\circ} \mathrm{C}\right.$; calculated in this study) as previously detailed in Giannakourou and Taoukis (2003). The models developed from isothermal experiments were validated at dynamic conditions (fluctuating temperatures from -8 to $-18{ }^{\circ} \mathrm{C}$ ). The results of validation tests showed that the developed kinetic models can be adequately used at variable temperature conditions, within the same range and duration of temperature fluctuations, to predict the kiwifruit quality and consequently the remaining shelf life. For this purpose, the quality change rates derived from the models were compared to the respective experimental values [Figs. $2(\mathrm{a} 2, \mathrm{~b} 2$ and $\mathrm{c} 2)]$. The models predicted satisfactory results, as the relative error (RE) values, calculated using Eq. 5:

$$
\% R E=\frac{k_{\text {exp }}-k_{f i t t e d}}{k_{\text {exp }}} \times 100
$$


48 | Dermesonlouoglou et al.

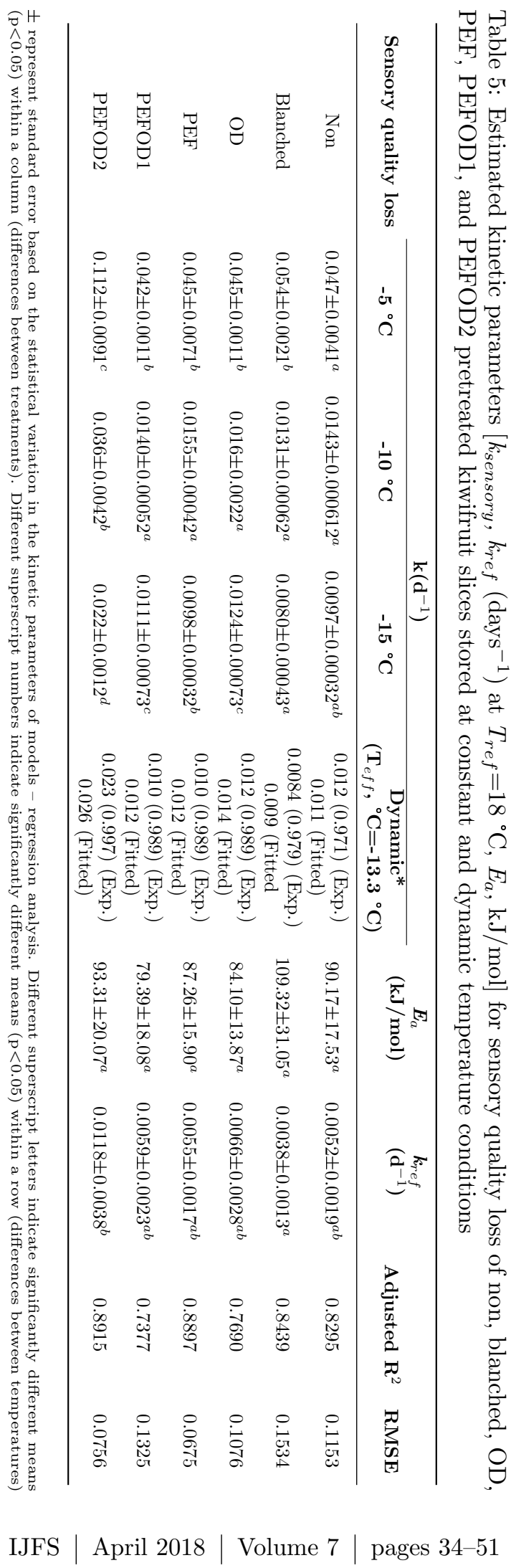


where within the $20 \%$ limit of acceptance for sensory evaluation (\%RE:-10.0-+4.2; all samples), vitamin C loss (\%RE:-20.0-+9.8; all samples) and instrumentally measured colour change (\%RE:-20.0-+11.8; apart from PEF samples where $\% \mathrm{RE}>20)$., These models adequately predict the quality deterioration of frozen kiwifruit slices.

\section{Conclusions}

PEF and OD could lead to adequate mass exchange, adequate decrease of $\mathrm{a}_{w}$ and improved quality characteristics of processed kiwifruit. The optimum processing conditions were OD: $\mathrm{T}_{O D}=35{ }^{\circ} \mathrm{C}, \mathrm{t}_{O D}=60 \mathrm{~min}$, and PEFOD1: $\mathrm{E}_{P E F}=1.8 \mathrm{kV} / \mathrm{cm}(250 \mathrm{p}), \mathrm{T}_{O D}=35^{\circ} \mathrm{C}, \mathrm{t}_{O D}=$ $30 \mathrm{~min}$ to have $\mathrm{a}_{w}$ decrease from 0.95 to 0.92 , acceptable colour, increased firmness, low drip loss and high vitamin $\mathrm{C}$ content. Increase of OD time from 30 to 60 min for PEF pretreated kiwifruit slices did not lead to better final product quality and sensory characteristics. The shelf life calculation was based on different criteria for each sample. The shelf life determining criteria were found to be colour change (expressed by $\Delta \mathrm{E}_{\text {final }}=5$ ) for blanched, PEF as well as PEFOD1 samples, sensory quality (expressed by the score given for the overall quality and acceptability) for OD and PEFOD2 samples, and vitamin retention for blanched samples $\left(\mathrm{C}_{v i t C}=0.30 \mathrm{C}_{v i t C, 0}\right)$, respectively. Based on this study, it could be suggested that (i) combined PEF and OD may have a potential as a preprocessing step in the manufacture of sensitive frozen fruit products, and (ii) the application of $\mathrm{PEF}$ alone as a prefreezing step may not be recommended.

\section{References}

Ade-Omowaye, B. I. O., Taiwo, K. A., Eshtiaghi, N. M., Angersbach, A., \& Knorr, D. (2003). Comparative evaluation of the effects of pulsed electric field and freezing on cell membrane permeabilisation and mass transfer during dehydration of red bell peppers. Innovative Food Science $\&$ Emerging
Technologies, 4(2), 177-188. doi:https:// doi.org/10.1016/S1466-8564(03)00020-1

Ade-Omowaye, B. I. O., Talens, P., Angersbach, A., \& Knorr, D. (2003). Kinetics of osmotic dehydration of red bell peppers as influenced by pulsed electric field pretreatment. Food Research International, 36(5), 475483. doi:10.1016/S0963-9969(02)00195-3

Amami, E., Vorobiev, E., \& Kechaou, N. (2005). Effect of pulsed electric field on the osmotic dehydration and mass transfer kinetics of apple tissue. Drying Technology, 23(3), 581-595. doi:10.1081/DRT-200054144

Amami, E., Vorobiev, E., \& Kechaou, N. (2006). Modelling of mass transfer during osmotic dehydration of apple tissue pre-treated by pulsed electric field. LWT-Food Science and Technology, 39(9), 1014-1021. European Symposium on Apple Processing, Rennes, FRANCE, MAR 16-18, 2005. doi:10.1016/ j.lwt.2006.02.017

Bressa, F., Dalla Rosa, M., \& Mastrocola, D. (1997). Use of direct osmosis treatment to produce minimally processed kiwifruit slices in a continuous pilot plant. In E. Sfakiotakis \& J. Porlingis (Eds.), Third international symposium on kiwifruit, vols 1 and 2 (444, 1\&2, pp. 649-654). ACTA HORTICULTURAE. 3rd International Symposium on Kiwifruit, ARISTOTLE UNIV, THESSALONIKI, GREECE, SEP 19-22, 1995.

Cao, H., Zhang, M., Mujumdar, A., Du, W. H., \& Sun, J. C. (2006). Optimization of osmotic dehydration of kiwifruit. Drying Technology, 24(1), 89-94. doi:10 . 1080/ 07373930500538741

Castro-Giraldez, M., Tylewicz, U., Fito, P. J., Dalla Rosa, M., \& Fito, P. (2011). Analysis of chemical and structural changes in kiwifruit (actinidia deliciosa cv hayward) through the osmotic dehydration. Journal of Food Engineering, 105(4), 599-608. doi:10.1016/j.jfoodeng.2011.03.029

Dermesonlouoglou, E. K., Giannakourou, M., \& Taoukis, P. S. (2007). Stability of dehydrofrozen tomatoes pretreated with alternative osmotic solutes. Journal of Food Engineering, 78(1), 272-280. doi:10.1016/j. joodeng.2005.09.026 
$50 \mid$ Dermesonlouoglou et al.

Dermesonlouoglou, E. K., Giannakourou, M., \& Taoukis, P. S. (2016). Kinetic study of the effect of the osmotic dehydration pretreatment with alternative osmotic solutes to the shelf life of frozen strawberry. Food and Bioproducts Processing, 99, 212-221. doi:10.1016/j.fbp.2016.05.006

Dermesonlouoglou, E. K., Pourgouri, S., \& Taoukis, P. S. (2008). Kinetic study of the effect of the osmotic dehydration pretreatment to the shelf life of frozen cucumber. Innovative Food Science \& Emerging Technologies, 9(4), 542-549. doi:10.1016/j. ifset.2008.01.002

Dermesonlouoglou, E. K., Zachariou, I., Andreou, V., \& Taoukis, P. S. (2016, October). Effect of pulsed electric fields on mass transfer and quality of osmotically dehydrated kiwifruit. Food and Bioproducts Processing, $100(\mathrm{~B}, \quad$ SI), 535-544. 29th International Conference of the European-Federation-of-FoodScience-and-Technology (EFFoST), Athens, GREECE, NOV 10-12, 2015. doi:10.1016/j.fbp.2016.08.009

Du, G., Li, M., Ma, F., \& Liang, D. (2009). Antioxidant capacity and the relationship with polyphenol and vitamin $\mathrm{c}$ in actinidia fruits. Food Chemistry, 113(2), 557-562.

Escriche, I., Garcia-Pinchi, R., Andres, A., \& Fito, P. (2000). Osmotic dehydration of kiwifruit (actinidia chinensis): fluxes and mass transfer kinetics. Journal of Food Process Engineering, 23(3), 191-205. doi:10. 1111/j.1745-4530.2000.tb00511.x

Ferrando, M. \& Spiess, W. E. L. (2001). Cellular response of plant tissue during the osmotic treatment with sucrose, maltose, and trehalose solutions. Journal of Food Engineering, 49(2-3), 115-127. doi:10.1016/S0260$8774(00) 00218-1$

Giannakourou, M. C. \& Taoukis, P. S. (2003). Kinetic modelling of vitamin $\mathrm{c}$ loss in frozen green vegetables under variable storage conditions. Food Chemistry, 83(1), 33-41. doi:10.1016/S0308-8146(03)00033-5

Gianotti, A., Sacchetti, G., Guerzoni, M. E., \& Dalla Rosa, M. (2001). Microbial aspects on short-time osmotic treatment of kiwifruit. Journal of Food Engineering, 49(2-
3), 265-270. doi:10.1016/S0260-8774(00) 00213-2

International Organization for Standardization. (2012). ISO 8586-1: Sensory analysis - general guidance for the selection, training and monitoring of selected assessors and expert sensory assessors. Retrieved from https:// www.iso.org/standard/45352.html

Jemai, A. B. \& Vorobiev, E. (2002). Effect of moderate electric field pulses on the diffusion coefficient of soluble substances from apple slices. International Journal of Food Science and Technology, 37(1), 73-86. doi:10.1046/j.1365-2621.2002.00516.x

Kaya, A., Aydm, O., \& Kolayli, S. (2010). Effect of different drying conditions on the vitamin c (ascorbic acid) content of hayward kiwifruits (actinidia deliciosa planch). Food and Bioproducts Processing, 88(C23), 165-173. doi:10.1016/j.fbp.2008.12.001

Knorr, D. \& Angersbach, A. (1998). Impact of high-intensity electric field pulses on plant membrane permeabilization. Trends in Food Science 83 Technology, 9(5), 185191. doi:10.1016/S0924-2244(98)00040-5

Knorr, D., Geulen, M., Grahl, T., \& Sitzmann, W. (1994). Food application of highelectric-field pulses. Trends in Food Science E Technology, 5(3), 71-75. doi:10.1016/ 0924-2244(94)90240-2

Krupa, T., Latocha, P., \& Liwinska, A. (2011). Changes of physicochemical quality, phenolics and vitamin c content in hardy kiwifruit (actinidia arguta and its hybrid) during storage. Scientia Horticulturae, 130(2), 410-417. doi:10.1016/ j . scienta.2011.06.044

Latocha, P., Krupa, T., Wolosiak, R., Worobiej, E., \& Wilczak, J. (2010). Antioxidant activity and chemical difference in fruit of different actinidia sp. International Journal of Food Sciences and Nutrition, 61(4), 381394. doi:10.3109/09637480903517788

Lebovka, N. I., Bazhal, M. I., \& Vorobiev, E. (2001). Pulsed electric field breakage of cellular tissues: visualisation of percolative properties. Innovative Food Science \& Emerging Technologies, 2(2), 113-125. doi:https : / / doi . org / 10 . 1016 / S1466 8564(01)00024-8 
Pulsed electric field pretreated osmodehydrofrozen kiwifruit $\mid 51$

Leong, L. P. \& Shui, G. (2002). An investigation of antioxidant capacity of fruits in singapore markets. Food Chemistry, 76(1), 6975. doi:10.1016/S0308-8146(01)00251-5

Lim, J. (2011). Hedonic scaling: a review of methods and theory. Food Quality and Preference, 22(8), 733-747. doi:10.1016/j . foodqual.2011.05.008

Montefiori, M., McGhie, T. K., Hallett, I. C., \& Costa, G. (2009). Changes in pigments and plastid ultrastructure during ripening of green-fleshed and yellow-fleshed kiwifruit. Scientia Horticulturae, 119(4), 377-387. doi:10.1016/j.scienta.2008.08.022

Orikasa, T., Koide, S., Okamoto, S., Imaizumi, T., Muramatsu, Y., Takeda, J.-i., ... Tagawa, A. (2014). Impacts of hot air and vacuum drying on the quality attributes of kiwifruit slices. Journal of Food Engineering, 125, 51-58. doi:10.1016/j.jfoodeng . 2013.10.027

Panarese, V., Tylewicz, U., Santagapita, P., Rocculi, P., \& Dalla Rosa, M. (2012). Isothermal and differential scanning calorimetries to evaluate structural and metabolic alterations of osmo-dehydrated kiwifruit as a function of ripening stage. Innovative Food Science \& Emerging Technologies, 15, 6671. doi:10.1016/j.ifset.2012.04.001

Parniakov, O., Bals, O., Lebovka, N., \& Vorobiev, E. (2016). Effects of pulsed electric fields assisted osmotic dehydration on freezing-thawing and texture of apple tissue. Journal of Food Engineering, 183, 3238. doi:10.1016/j.jfoodeng.2016.03.013

Rastogi, N. K., Eshtiaghi, M. N., \& Knorr, D. (1999). Accelerated mass transfer during osmotic dehydration of high intensity electrical field pulse pretreated carrots. Journal of Food Science, 64(6), 1020-1023. doi:10. 1111/j.1365-2621.1999.tb12272.x

Stanley, R., Wegrzyn, T., \& Saleh, Z. (2007). Kiwifruit processed products. In A. Ferguson, E. Hewett, F. Gunson, \& C. Hale (Eds.), Proceedings of the 6th international symposium on kiwifruit, vols 1 and 2 (753, pp. 795-799). ACTA HORTICULTURAE. 6th International Symposium on Kiwifruit, Rotorua, NEW ZEALAND, FEB 20-24, 2006 .
Stec, M. G. H., Hodgson, J. A., Macrae, E. A., \& Triggs, C. M. (1989). Role of fruit firmness in the sensory evaluation of kiwifruit (actinidia-deliciosa cv hayward). Journal of the Science of Food and Agriculture, 47(4), 417-433. doi:10.1002/jsfa.2740470404

Taiwo, K. A., Angersbach, A., Ade-Omowaye, B. I. O., \& Knorr, D. (2001). Effects of pretreatments on the diffusion kinetics and some quality parameters of osmotically dehydrated apple slices. Journal of Agricultural and Food Chemistry, 49(6), 28042811. doi:10.1021/jf0009798

Talens, P., Escriche, I., Martinez-Navarrete, N., \& Chiralt, A. (2003). Influence of osmotic dehydration and freezing on the volatile profile of kiwi fruit. Food Research International, 36(6), 635-642. doi:10.1016/S09639969(03)00016-4

Tedjo, W., Taiwo, K. A., Eshtiaghi, M. N., \& Knorr, D. (2002). Comparison of pretreatment methods on water and solid diffusion kinetics of osmotically dehydrated mangos. Journal of Food Engineering, 53(2), 133142. doi:10.1016/S0260-8774(01)00149-2

Tocci, A. M. \& Mascheroni, R. H. (2008). Some thermal properties of fresh and osmotically dehydrated kiwifruit above and below the initial freezing temperature. Journal of Food Engineering, 88(1), 20-27. doi:10. 1016/j.jfoodeng.2007.10.014

Tsironi, T., Dermesonlouoglou, E., Giannakourou, M., \& Taoukis, P. (2009). Shelf life modelling of frozen shrimp at variable temperature conditions. LWT-Food Science and Technology, 42(2), 664-671. doi:10.1016/j.lwt.2008.07.010

Tylewicz, U., Fito, P. J., Castro-Giraldez, M., Fito, P., \& Rosa, M. D. (2011). Analysis of kiwifruit osmodehydration process by systematic approach systems. Journal of Food Engineering, 104(3), 438-444. doi:10.1016/ j.jfoodeng.2011.01.007 